\title{
Further Contributions to the Cytology of the Ascomycetes.
}

BY

\author{
H. C. I. FRASER, D.Sc., F.L.S., \\ Lecturer in Botany, University College, Nottingham,
}

AND

E. J. WELSFORD, F.L.S., Botanical Assistant, Royal Holloway College, University of London.

With Plates XXVI and XXVII, and a Figure in the Text.

$\mathrm{R}$ ECENT investigations by one of us (13) have shown that in Humaria rutilans a meiotic reduction, involving transverse fission of the heterotype chromosomes, takes place in the first two divisions in the ascus, and further, that it is followed, in the third mitosis, by a second, or brachymeiotic reduction of a simpler type.

These processes accord with the observations of Harper (19) on Phyllactinia but have not been described in other forms; the present researches were undertaken as a first step towards ascertaining whether they are of general occurrence among Ascomycetes. We have found, in the two species with which this paper deals, intermediate stages between the early union of the chromosomes in Phyllactinia and their independence during the stages which precede reduction in Humaria rutilans and in higher plants and animals.

Material was obtained in Windsor Park during the autumns of 1906 and I907, and was fixed in the field in various strengths of Flemming's fluid. Before staining, many of the slides were immersed for three or four hours in a solution of pepsin ${ }^{1}$ and 0.2 per cent. hydrochloric acid at a temperature of $38^{\circ} \mathrm{C}$. This treatment facilitated the study of the chromatin. Sections were cut $5^{-10} \mu$ in thickness and were stained with Heidenhain's iron-haematoxylin or with Flemming's triple stain.

\section{OTIDEA AURANTIA.}

This species has a large, orange apothecium which increases considerably in size after the asci have begun to form. In the early stages of development a large cell with scanty contents is present, and represents,

[Annals of Botany, Vol. XXII. No. I.XXXVII. July, 1908.]

\footnotetext{
${ }^{1}$ See Farmer and Digby (10), p. 165 .
} 
we believe, a disused ascogonium (Pl. XXVI, Fig. I). The hypothecium is pseudo-parenchymatous, and consists of polygonal, closely placed cells ; this arrangement differs from that in $H$. rutilans where the ramifications of individual hyphae can be distinctly traced. The hypothecial nuclei are too minute for satisfactory investigation, and consequently the attempt was early abandoned to observe the first and presumably pseudapogamous fusion.

In the sub-hymenial layer the ascogenous hyphae are distinguished by their dense contents. The nuclei are vacuolate, and, though larger than those of the hypothecium, they are still difficult to study. We found no indication of a conjugate arrangement.

In Otidea aurantia, Mass., as in $H$. rutilans, the first divisions in the ascus constitute a meiotic phase, and here also they correspond closely to the description given by Farmer and Moore (9). The various stages are almost diagrammatic in clearness (Figs. 2-IO), and we feel no doubt as to their significance.

After the first contraction (Fig. 2) the spireme splits longitudinally (Fig. 3), synapsis takes place (Fig. 4), and four loops are formed (Fig. 5); in the limbs of these the longitudinal fission is seen, and they break apart to form the four gemini (Moore and Embleton (21)) or bivalent chromosomes (Fig. 6) which undergo considerable contraction. A transverse fission takes place on the heterotype spindle (Fig. 8), and the longitudinal fission is completed on that of the homotype (Figs. II, I2). Four chromosomes thus travel to each pole both in the first (Fig. 9) and in the second mitosis (Figs. I 2, I3).

During the early stages of meiosis the fusion in the ascus takes place.

The third division is inaugurated by a contraction ${ }^{1}$ of the chromatin thread (Fig. 14) and two or sometimes four chromatin masses become visible (Figs. I5, I6). The spindle is then formed and in the early metaphase two long chromosomes are observed (Fig. 17). The exact sequence of the prophases is difficult to determine, but it seems clear that the two chromosomes of the metaphase are bivalent and that each represents two of those which pass to the poles in the previous mitosis. On the spindle they divide, and two small daughter-chromosomes travel to each pole.

This division appears, like the corresponding one in $H$. rutilans, to be brachymeiotic in character and to result in the separation of different portions of the nuclear thread.

During all three divisions in the ascus one or two granules are frequently seen within the nuclear area (Figs. 8, I3, I7). They may be connected with the centrosome by 'fibres' resembling those of the spindle

1 Contraction is sometimes seen in the daughter nuclei after the first mitosis, the chromatin forming a dense mass at the end of the nucleus remote from the plane of division. This differs from the contraction of a chromatin thread observed in the third mitosis here and in both divisions in $P$. vesiculosa; it probably represents a stage of reconstruction comparable to Fig. $3^{2}$. 
(Figs. I , 20), but they do not travel towards the poles (Fig. 10). Similar radiations are sometimes attached to the nucleolus (Fig. 18).

Spindle formation and the development of the spores take place as in Peziza vesiculosa and will be described in connexion with that species.

\section{PEZIZA VESICULOSA.}

Peziza vesiculosa, Bull. (Pustularia vesiculosa, Fckl.), has a conspicuous buff apothecium in which the phenomenon of 'puffing' is well shown. It has been studied by a number of observers; in it Dangeard (7) first saw the fusion in the ascus, and it has been more recently investigated by both Maire (20) and Guillermond (14).

The hypothecium is very similar in appearance to that of Otidea aurantia but an ascogonium was not recognized. Here also we were unable to observe a pseudapogamous fusion.

We can confirm Maire's statement that, before the bending over of the crozier, the nuclei in the ascogenous hyphae are not conjugately arranged, but we have been unable to recognize with certainty the single division which he describes as giving rise to the nuclei destined by a simultaneous mitosis to produce the nuclei of the ascus.

The divisions in the ascogenous hyphae are quite normal (Figs. 2I, 22) and show about eight chromosomes on the equatorial plate (Fig. 2I). Afterwards the subterminal cell of the hypha is cut off and gives rise to the ascus, as described by Dangeard. In the cases observed by us the fusion in the ascus (Fig. 23) took place at about the time of the first meiotic contraction.

The prophases of the first division are not as clearly defined as in Otidea ; the regular occurrence, however, of contraction phases (Figs. 24, 26), as described also by Maire, sufficiently indicates the existence of the usual reduction at this stage.

Guillermond describes the formation of eight chromosomes, the spindle being at the same time developed in the centre of the nuclear area. In our material, however, spindle formation took place by the method recorded by Harper $\left(\mathrm{I}_{5}, 19\right)$ for Erysiphe and other species. The two centrosomes are first observed lying close together (Fig. 27) with a cone of radiations passing out from each. A little later, as they move apart, the radiations come into contact (Fig. 28) and a spindle is formed. It is at first a good deal bent, and is placed across the shorter axis of the nucleus (Fig. 28); as development proceeds it straightens out and usually comes to lie parallel to the longitudinal plane of the ascus (Figs. 29-3 I). The centrosome remains firmly attached to the nuclear membrane, so that the latter is often drawn inwards when the spindle is short (Fig. 29).

In the early stages of division eight chromosomes are visible on the 
spindle (Figs. 28, 29) and, in the anaphase, eight travel to each pole (Fig. 30). We were not able to find four chromosomes, as described by Maire, in definitely uncut nuclei at any stage during this division.

On the spindle of the second or homotype division (Fig. 34), and also on the spindle of the third (Fig. $3^{8}$ ), four chromosomes appear; they divide so that, in both cases, four pass to each daughter-nucleus (Figs. 35, 39,40 ). Their formation is preceded by the withdrawal of the chromatin towards one side of the nucleus (Fig. 33); this may be regarded as analogous to one of the meiotic contractions and as indicating the moment of pairing of the eight chromosomes of the heterotype telophase. Since contraction takes place in both the second and the third prophase (Figs. 33, 37 ) it would seem that the union of the paired chromosomes is very slight and breaks down between the end of the second and the beginning of the third division; this conclusion is also borne out by Maire's and Guillermond's observations.

Guillermond has described eight chromosomes throughout the second and third divisions, and Maire eight protochromosomes in both prophases. In our material the number in the anaphases and early telophases of these divisions is clearly four, but it is not impossible that, in some cases, the eight chromatin bodies found on the spindle may represent the 'protochromosomes' of Maire rather than, as we have considered, the separated daughter-chromosomes.

In either case, by the end of the third division a second reduction has been accomplished and the eight chromosomes of the heterotype telophase have been replaced by four. The process by which this is accomplished appears to correspond to that in $H$. rutilans and $O$. aurantia.

Before the third division is complete spore formation begins. The spindle elongates, and during the telophases and the early stages of reconstruction of the daughter-nucleus a beak is formed (Figs. 43, 44) and appears to push actively towards the periphery. At the same time changes take place in the cytoplasm (Figs. 4I-44); its staining capacity increases and the astral rays are bent backwards, giving the arrangement first described by Harper (15). The appearance of the rays suggests that currents of altered cytoplasm are flowing back around the advancing nuclear beak. A little later the upper portion of the spore is seen to be defined by a limiting membrane (Fig. 45), while the lower part is irregularly outlined by the sides of neighbouring vacuoles, and becomes rounded off at a later stage.

The arrangement of the vacuoles is in general very regular: a large one fills the lower part of the ascus and another occupies its apex. Seven others, more or less well-defined, are left by the first, second, and third mitoses; and the main body of cytoplasm is thus broken up into eight masses within which spore formation takes place (Fig. 44). 
Irregularly shaped and multinucleate spores, and also asci which contained more than two nuclei at their formation, were several times observed.

The paraphyses are septate; in the earlier stages of development their nuclei are small and contain a single nucleolus, the rest of the stainable material being regularly distributed (Fig. 46). Later the nuclei become enlarged and vacuolate, and the nuclear contents are massed into deeply staining lumps (Fig. 47).

\section{The Divisions in the Ascus.}

The chromosomes have been counted in comparatively few Ascomycetes, a great part of our knowledge being due to the investigations of Maire (20) and of Guillermond (14). Harper, also, has studied several species and especially Phyllactinia corylea (19), where he found eight chromosomes throughout the life-history. This case is somewhat peculiar, as the chromosomes pair directly after the union of the nuclei, and thus their number remains unaltered while their valency is first doubled (in the oogonium) and later quadrupled (on the fusion in the ascus). In the same way reduction consists not in the diminution of the number of the chromosomes but in the halving of their valency.

In Humaria rutilans (13) the number of chromosomes in the mycelial nuclei before fertilization has not been counted; in the ascogenous hyphae (after the pseudapogamous fusion) there are sixteen; and the same number appears throughout the first and second divisions in the ascus and in the prophases of the third, when the meiotic reduction and asexual fusion are complete. In the third telophase there are only eight chromosomes and a second reduction--the brachymeiotic-has thus taken place.

In Otidea aurantia we were unable to count the chromosomes before the fusion in the ascus. The first two divisions in the ascus are, however, obviously meiotic, and the chromosomes are then four in number. In the third prophase two chromosomes appear, and these divide on the spindle so that two pass to each pole.

In Peziza vesiculosa the nuclei have been investigated by Maire (20) and by Guillermond (14), as well as by ourselves. Guillermond finds eight chromosomes throughout the divisions in the ascus. Maire also observes eight in all three prophases, but he regards these as protochromosomes and describes them as fusing to form four in the metaphase. In the late anaphase of the first division eight chromosomes reappear and are interpreted by him as representing the prematurely separated daughterchromosomes of the homotype mitosis; in the second and third anaphases he finds only four. 
We have observed eight chromosomes in the ascogenous hyphae, and also, like Guillermond, throughout the first division in the ascus. We regard eight, therefore, as double the postmeiotic number, produced either (in the ascogenous hyphae) by a pseudapogamous fusion alone, or (in the ascus) by an additional fusion combined with meiotic reduction.

In the second and third divisions we find four chromosomes throughout. It seems to us, therefore, that brachymeiosis takes place, as in Humaria rutilans and Otidea aurantia, in the third division in the ascus, but that, just as in Otidea the chromosomes unite in the third prophase, so here they are paired during the prophases of the previous division. If this union were somewhat deferred, Maire's eight chromatin masses would of course appear, fusing later to form four; and if, as in Humaria mutilans, it were altogether omitted the eight chromosomes of Guillermond would be observed throughout the second division and in the third prophase. It is to be regretted, however, that neither author figures all the stages he describes.

Maire (20) and Guillermond (14) have also investigated Galactinia succosa. Here they each find four chromosomes on the heterotype spindle preceded by a varying number of protochromosomes. In the early anaphase they find four chromosomes passing to each pole, but in the late anaphase eight are present. Eight also appear in the second prophase and unite on the spindle to form four. Four were observed in the second anaphase and throughout the third division. ${ }^{1}$

From the observations detailed above, the following points seem to us to emerge :-

(I) In Humaria rutilans there is no obvious mechanism for the separation of allelomorphs in brachymeiosis.

(2) In Otidea aurantia such a mechanism is apparent, the chromosomes uniting in pairs during the brachymeiotic prophase.

(3) In Peziza vesiculosa the time of the corresponding union seems to be variable; it took place in our material during the early stages of the division which precedes brachymeiosis.

(4) In Galactinia succosa pairing is brought about on the spindle of the first division, but it is very unstable, the four chromosomes separating into eight from time to time.

(5) In Phyllactinia corylea the chromosomes pair immediately after the nuclear union in the ascus, and the same is the case with regard to sexual fusion.

1 Another case of great interest is that of Morchella esculenta, where Maire (20), after observing eight chromatin bodies in the prophase of the first division in the ascus, finds four in the metaphase and anaphase of the third, and also in the division of the spore nuclei. This, so far as we are aware, is the only instance in which the chromosomes have been counted between brachymeiosis and fertilization. Unfortunately the species has not been fully investigated. 
We have represented these differences diagrammatically in the accompanying text-figure, in which, for the sake of uniformity, we have assumed the minimum number of chromosomes to be two throughout.

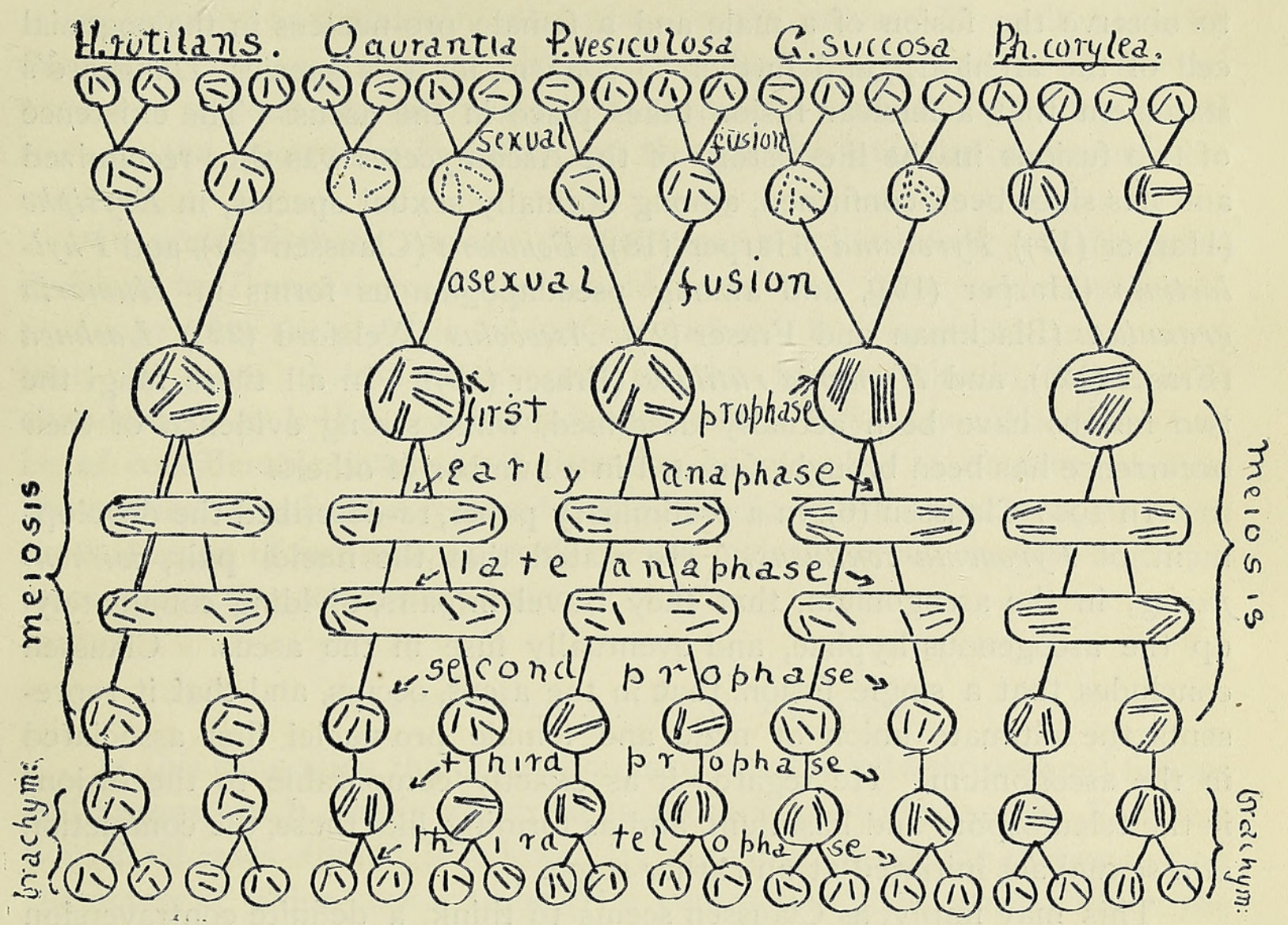

The Sexuality of the Ascomycetes.

In the development of a knowledge of these forms history has more than once repeated itself.

In I79I Bulliard (4) described the asci as female organs and suggested that their fertilization was accomplished by the bursting of the paraphyses, which he regarded as male.

In and after 1863 the classical researches of De Bary (8) and his pupils established the existence of archicarps and antheridia in a number of species ; they brought forward evidence of the occurrence of fertilization at this stage in some cases, and of a corresponding 'reduced' development in others. They regarded the ascus as a spore mother cell.

From I 872 onwards the extensive researches of Brefeld (3) appeared. He denied the sexual character of the organs observed by De Bary and attributed a vegetative significance to their fusions.

In I894 Dangeard (7), investigating Peziza vesiculosa and some other forms, discovered the fusion in the ascus. He accepted the sexuality of 
the Ascomycetes in a new sense, held the ascus to be an egg in which fertilization occurred, and regarded the archicarp and antheridium, when present, as merely vestigial.

In I895 Harper (16) reinvestigated Sphaerotheca humuli; he was able to observe the fusion of a male and a female pro-nucleus in the oogonial cell of the archicarp, and further to confirm, for this species, Dangeard's statement that a nuclear fusion takes place in the ascus. The existence of two fusions in the life-history of the Ascomycetes was thus recognized and has since been confirmed, among normally sexual species, in Erysiphe (Harper (17)), Pyronema (Harper (18)), Boudiera (Claussen (5)), and Phyllactinia (Harper (19)), and among pseudapogamous forms in Humaria gramulata (Blackman and Fraser (2)), Ascobolus (Welsford (22)), Lachnea (Fraser (12)), and Humaria rutilans (Fraser (13)). In all these fungi the two fusions have been actually described, while strong evidence of their occurrence has been brought forward in a number of others.

In 1907 Claussen (6), in a preliminary paper, re-described the development of Pyronema confluens. He stated that the nuclei pair, without fusing, in the ascogonium, that they travel in pairs, dividing conjugately, up the ascogenous hyphae, and eventually fuse in the ascus. Claussen concludes that a single fusion, that in the ascus, occurs, and that it represents the ultimate union of male and female pro-nuclei first associated in the ascogonium. He regards it as exactly comparable to the fusions in the teleutospore and basidium, and as forming, like these, the completion of a sexual act initiated at an earlier stage.

This may imply, as Claussen seems to think, a definite contraversion of the fusions observed by earlier workers and by himself (5), and his generalization is so far satisfactory that it brings the Ascomycetes into line with the Uredineae and other Basidiomycetes, and does away with the difficult question of the significance of the second, or so-called asexual, fusion.

It might perhaps be conceivable, in accordance with this view, that confusion should have arisen, in earlier work, with regard to the behaviour of the minute nuclei of the coenogamete, but it seems to us improbable that the sequence of stages in uninucleate forms, such as the mildews, should have been misinterpreted. In these species not only has the first fusion been observed, but a stage has been several times recorded (Harper (16), (17), (19), Blackman and Fraser (1)) when the antheridium is already empty and the oogonium contains a single mucleus; such a stage follows the entrance of the male nucleus into the oogonium and obviously implies fusion.

Claussen's views, moreover, as applied by him to Ascomycetes in general, are difficult to reconcile with the observations recorded both here and previously, as to the reduction phenomena in the ascus. 
On the other hand, it has already been noticed that in pseudapogamous forms fusion may be delayed till the nuclei are just leaving the ascogonium, and that in $H$. rutilans it occurs in the ascogenous hyphae; it seems possible, then, that in Pyronema confuens, the fusion may sometimes be so much retarded as to actually take place in the ascus. There is, however, necessarily no proof that the large nuclei figured by Claussen in the ascogenous hyphae are not the result of fusion, even though they travel towards the hymenium in pairs, and though the later fusion stages were not seen.

In view of these various possibilities, a full account of the ascus divisions in Pyronema confluens would be of very great value and would no doubt solve the problem of nuclear fusion. It is quite to be expected that, in some Ascomycetes, one of the fusions should have been abandoned; and the conditions under which this may take place will be of considerable interest; it will also be of value to observe whether the method of reduction retained is the meiotic, which appears to represent the last stage of fertilization, or the brachymeiotic, which may be regarded as compensating an asexual fusion.

\section{Sexual and Asexual Fusions.}

In this connexion the distinction is of interest between asexual fusions and fusions which may be regarded as sexual in the widest sense. Fertilization, in all cases studied, is followed by a meiotic phase, the distinguishing characters of which appear to be (I) a contraction phase during which the chromatin filaments are temporarily massed atogether; (2) a longitudinal fission throughout the length of the spireme (this fission, though occasionally obscured, persists till the homotype metaphase, when it forms the line of separation of the daughter-chromosomes); (3) a second or synaptic contraction. Here the chromosomes become closely massed together, and, as the contraction loosens, their number, or that of the corresponding loops, may be counted.

Brachymeiosis is more variable; its most essential feature seems to be the formation of a given number of chromosomes, half of which pass to each daughter-nucleus. These chromosomes may be apparently independent or they may be paired at the beginning of the brachymeiotic division as in Otidea aurantia, or at an earlier stage as in Peziza vesiculosa and Phyllactinia; such pairing, in the two former cases, is associated with a contraction phase. ${ }^{1}$ It seems, therefore, that some mechanism exists for the orderly distribution of allelomorphs.

1 I have re-examined part of the material of Humaria rutilans from this point of view, but without finding a contraction either in the second or the third prophase. Such a result is quite to be expected, as there is no obvious pairing of the chromosomes in this species.-H. C. I. F. 
Apart from the premature longitudinal fission of the heterotype, and the consequent occurrence of the homotype division, the difference between the two methods of reduction seems to lie in the extra contraction of meiosis. In all probability this contraction is the second, since Moore and Embleton (21) have observed the formation of the gemini in the cockroach before a spireme appears, and Harper (19) has found synapsis in Phyllactinia where the chromosomes are already paired. These facts suggest that the first meiotic contraction rather than the second is connected with the union of the chromosomes.

It seems, then, that meiosis is distinguished from brachymeiosis by its synaptic phase, and it seems not unlikely that this indicates the moment of some interchange of material between the already paired allelomorphs. If this be the case, the opportunity for interchange must vary considerably according to the extent of the synaptic contraction; it would be of interest to ascertain whether there is any relation between this difference and the occurrence of mutation.

We are inclined to believe that brachymeiosis, since it lacks a second contraction, admits of less variation in its products than meiosis, and implies either the separation of the entire nuclei which fused, or at any rate a sorting of unaltered chromosomes. Similarly it might be possible to regard asexual fusion as essentially a temporary expedient, the result of such casual conditions as proximity (as when two nuclei associated in the same cell fuse); and sexual fusion, even when reduced, as a more permanent and significant process implying an interchange of parental material.

We are not prepared to suggest that the forms of reduction are never interchangeable ; but, while its phylogenetic history is perhaps the ultimate test of the nature of a fusion, it is noteworthy that there is no case known of a sexual process, however simplified, followed by any but a meiotic reduction.

\section{SPORE-FORMATION.}

Spore-formation in the Ascomycetes was first studied by Harper (15) in 1895 , and his account has been several times confirmed. He concludes that the spore is bounded by the fibres of the polar aster, which bend round and fuse laterally to form a membrane.

Faull (11), in 1905 , described the spore as cut out by the gradual differentiation, from the centrosome downwards, of a limiting layer of 'hyaline or finely granular' cytoplasm. This account, unlike Harper's, has been correlated with the processes observed in certain Phycomycetes.

In 1908 it was suggested by one of us (13) that the spore is in fact delimited by the astral rays, but that these represent currents flowing 
out from the centrosome. Our present studies, especially on Peziza vesiculosa, have strengthened this point of view. It has been suggested that the centrosome is the seat of fermentive activities. On this hypothesis the centrosome, as it pushes outwards through the cytoplasm at the end of the third division, might be regarded as constantly generating a ferment. This ferment would flow back in its wake and would delimit the spore by producing a chemical change in the area through which it was distributed. It would ordinarily tend, as in the polar aster, to flow out equally all round the centrosome, but in this case, owing to the movement of its source, it would flow especially backwards. Its effect would be limited in certain directions by the occurrence of vacuoles and by the presence of the ascus wall. Whether the changes which thus take place are due to enzyme activity or to some other agent, we conclude that while the spore is to some extent bounded by neighbouring vacuoles, the main factor in its delimitation is an alteration of the cytoplasm, originating at the centrosome, and essentially similar in character to that which produces the aster.

\section{Summary.}

I. In Otidea aurantia traces of a probably functionless ascogonium are present; no such structure was found in Peziza vesiculosa.

2. In both species the first and second divisions in the ascus constitute a meiotic phase; this was investigated in some detail in Otidea aurantia, and was found to correspond closely to the description given by Farmer and Moore, the first division being diaschistic.

3. Fusion in the ascus occurs at about the time of the first meiotic contraction.

4. A second reduction takes place in the third division in the ascus. In Otidea aurantia the chromosomes pair in the prophases of this division; in Peziza vesiculosa they unite at an earlier stage.

5. We regard the presence of both meiosis and brachymeiosis in these forms, as well as in those previously described, as additional evidence of the occurrence of two fusions in the life-history of Ascomycetes.

6. The number of chromosomes in the first division in the ascus is four in Otidea aurantia and eight in Peziza vesiculosa; after brachymeiosis is complete there are two chromosomes in Otidea, four in Peziza.

7. The spores are delimited to some extent by vacuoles, but mainly by the astral rays. It is suggested that these may represent the paths of activity of an enzyme generated at the centrosome and producing chemical changes in the surrounding cytoplasm. 


\section{LIST OF PAPERS.}

1. Blackman, V. H., and Fraser, H. C. I. ('05): Fertilization in Sphaerotheca. Ann. Bot., xix, h. 567 .

2. ('06): On the Sexuality and Development of the Ascocarp in Humaria gramulata. Quel. Proc. Roy. Soc., London, B. lxxvii, p. 354 .

3. Brefeld, O. ('72 et seq.) : Untersuchungen aus dem Gesammtgebiete der Mykologie. Leipzig.

4. Bulliard (1791): Histoire des Champignons de France, p. I 2.

5. Claussen, P. ('05): Zur Entwicklungsgeschichte der Ascomyceten: Boudiera. Bot. Zeit., lxiii, p. I.

6. $\left({ }^{\prime} 07\right)$ : Zur Kenntnis der Kernverhältnisse von Pyronema confluens. Ber. d. Dent. Bot. Gesell., xxv, p. 586 .

7. Dangeard, P. ('94-5): La Reproduction sexuelle des Ascomycètes. Le Botaniste, iv, p. 2 I.

8. De Bary, A. ('63): Ueber die Fruchtentwicklung der Ascomyceten. Leipzig.

9. Farmer, J. B., and Moore, J. E. S. ('05): On the Meiotic Phase (Reducing Division) in Animals and Plants. Q. J. M. S., 192, p. 489.

10. Farmer, J. B., and Digby, L. ( 07 ) : Studies in Apospory and Apogamy in Ferns. Ann. Bot.

11. Faull, J. H. ('05). Development of the Ascus and Spore Formation in Ascomycetes. Proc. Boston Soc. Nat. Hist. xxxii, p. 77.

12. Fraser, H. C. I. ('07): On the Sexuality and Development of the Ascocarp in Lachnea stercorea. Ann. Bot. xxi, p. 349 .

13. ('08): Contributions to the Cytology of Humaria rutilans. Ann. Bot., xxii, p. 35 .

14. Guillermond, M. A. ('05): Remarques sur la karyokinèse des Ascomycètes. Ann. Mycol., iii, p. 344 .

15. Harper, R. A. ('95): Beiträge zur Kenntnis der Kernteilung und Sporenbildung im Ascus. Ber d. Deutsch. Bot. Gesell., xiii, p. 67.

16. ('95): Entwicklung des Peritheciums bei Sphaerotheca castagnei. Ber. d. Deutsch. Bot. Gesell., xiii, p. 475 .

17. ('96): Ueber das Verhalten der Kerne bei der Fruchtentwickelung einiger Ascomyceten. Jahrb. f. wiss. Bot., xxix, p. 656 .

18. ('00): Sexual Reproduction in Pyronema confluens and the morphology of the Ascocarp. Ann. Bot. xiv, p. 32 I.

19. ('05): Sexual Reproduction and the Organization of the Nucleus in certain Mildews. Publ. Carnegie Inst., Washington, No. 37, p. I.

20. Maire, R. ('05): Recherches cytologiques sur quelques Ascomycètes. Ann. Mycol., iii, p. I 23. 21. Moore, J. E. S., and Embleton, A. ('06): 'On Synapsis in Amphibia.' Proc. Roy. Soc. B., vol. lxxvii, p. 555 .

22. Welsford, E. J. ('07): Fertilization in Ascobolus furfuraceus. New Phyt., vi, p. 136.

\section{EXPLANATION OF PLATES XXVI AND XXVII.}

Illustrating Dr. Fraser and Miss Welsford's paper on the Cytology of the Ascomycetes,

Figs. I-20, Otidea aurantia.

Fig. I. Section through ascogonium. $\times 95^{\circ}$.

\section{FIRST DIVISION.}

Fig. 2. Two nuclei in the ascus, showing first meiotic contraction. $\times 2800$.

Fig. 3. Fusion nucleus with longitudinally split spireme. $\quad \times 2800$.

Fig. 4. Synaptic contraction. $\times 2800$.

Fig. 5. Nucleus passing out of synapsis; four loops are apparent and show longitudinal fission. $\times 2800$. 
Fig. 6. Chromosomes; longitudinal fission visible in the limbs. $\times 2800$.

Fig. 7. Heterotype metaphase. $\times 2800$.

Fig. 8. The same; later stage. $\times 2800$.

Fig. 9. Anaphase. $\times 2800$.

Fig. 1o. Telophase. $\times 2800$.

\section{SECOND DIVISION.}

Fig. II. Homotype metaphase. $\times 2800$.

Fig. I 2. Anaphase; lower spindle cut obliquely. $\times 2800$.

Fig. I3. Telophase. $\times 2800$.

\section{THIRD DIVISION.}

Fig. 14. Brachymeiotic contraction. $\times 2800$.

Fig. I5. Later prophase. $\times 2800$.

Fig. 16. Later prophase. $\times 2800$.

Fig. I 7. Metaphase. $\times 2800$.

Fig. 18. Early anaphase, showing radiations passing out towards nucleolus. $\quad \times 2800$.

Fig. 19. Anaphase. $\times 2800$.

Fig. 20. Telophase. $\times 2800$.

Figs. 2 I-47, Peziza vesiculosa.

Fig. 2 I. Equatorial plate in ascogenous hypha; formation of crozier. $\times 2600$.

Fig. 22. Telophase in ascogenous hypha; the plane of section is probably at right angles to the crozier. $\times 2600$.

Fig. 23. Nuclear fusion in ascus. $\times 2600$.

\section{FIRST DIVISION.}

Fig. 24. First contraction of the chromatin. $\times 2600$.

Fig. 25. Longitudinal fission of spireme. $\times 2600$.

Fig. 26. Synaptic stage. $\times 2600$.

Fig. 27. Early stage of spindle formation; heterotype chromosomes formed; part of the nucleus has been cut away. $\times 2600$.

Fig. 28. Spindle lying across shorter axis of nucleus; eight chromosomes present. $\times 2600$.

Fig. 29. Early metaphase. $\times 2600$.

Fig. 30. Anapháse. $\times 2600$.

Fig. 31. Telophase. $\times 2600$.

Fig. 32. Reconstruction of daughter-nuclei. $\times 2600$.

\section{SECOND DIVISION.}

Fig. 33. Contraction of chromatin. $\times 2600$.

Fig. 34. Metaphase, showing four chromosomes. $\times 2600$.

Fig. 35. Anaphase. $\times 2600$.

Fig. 36. Telophase. $\times 2600$.

\section{THIRD DIVISION AND SPORE FORMATION.}

Fig. 37. Contraction of chromatin. $\times 2600$.

Fig. 38. Metaphase, showing four chromosomes. $\times 2600$.

Fig. 39. Anaphase. $\times 2600$.

Fig. 40. Telophase; lower nucleus in polar view. $\times 2600$.

Fig. 4I. Slightly later telophase; astral rays increasing in prominence. $\times 2600$.

Fig. 42. Later stage, beginning of delimitation of spore. $\times 2600$.

Fig. 43. Spore formation; appearance of nuclear beak. $\times 2600$.

Fig. 44. Ascus, showing arrangement of vacuoles; reconstruction of nuclei almost complete; spore formation further advanced. $\times 2600$.

Fig. 45. Upper part of spore clearly delimited; lower part not yet defined. $\times 2600$.

Fig. 46. Young paraphyses. $\times 2600$.

Fig. 47. Older paraphysis, showing vacuolate and disintegrating nuclei. $\times 2600$.

$\mathrm{K} \mathrm{k} 2$ 
etruats of Botany.

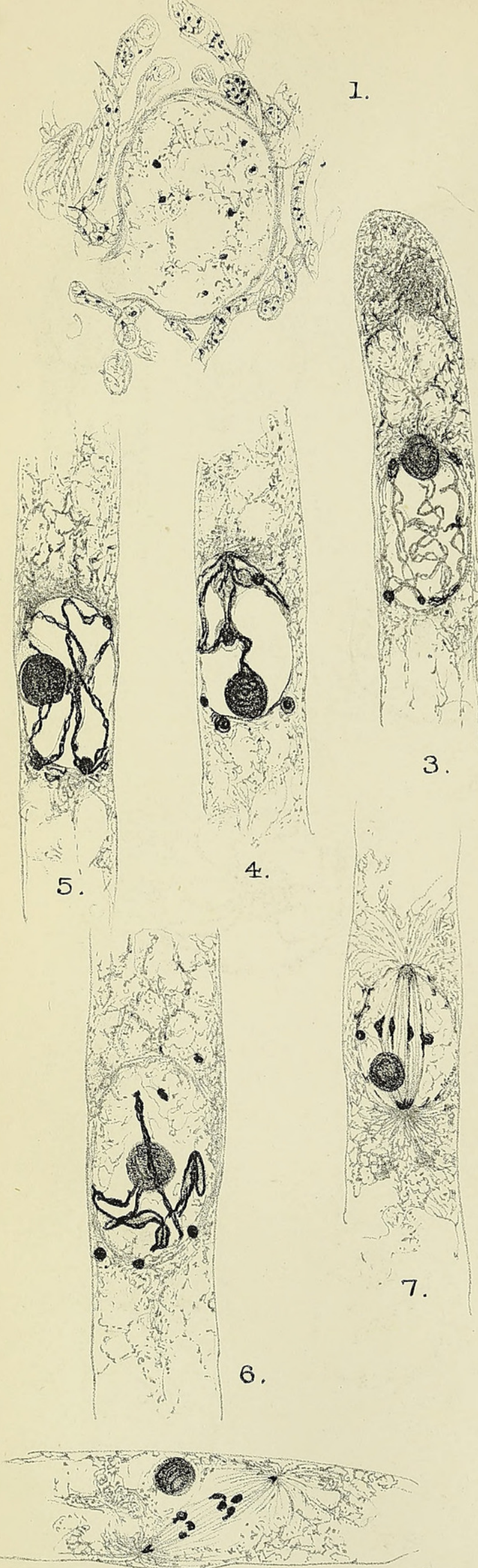

9.

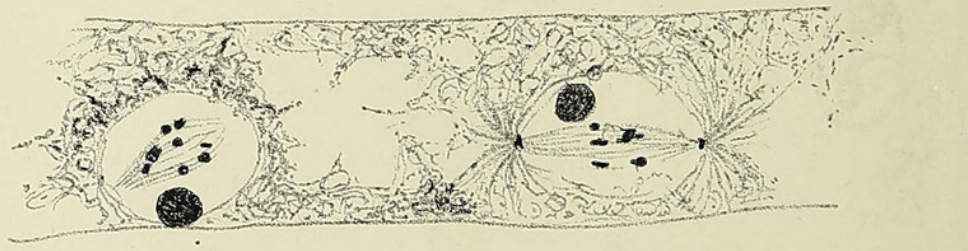

12

Fraser del.

FRASER AND WELSFORD - CY 
VoZ.XXII.PZ,XXVI.

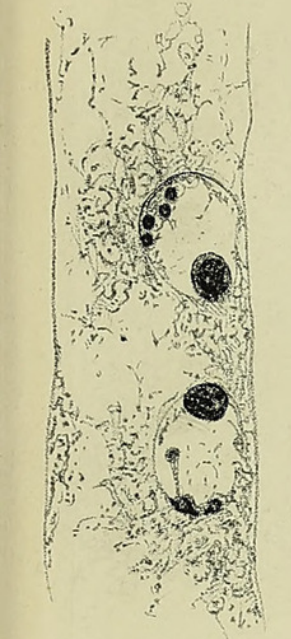

16.

17.

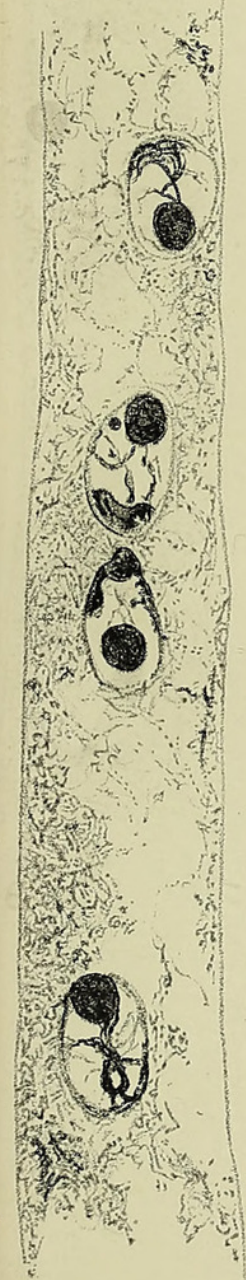

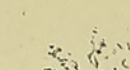
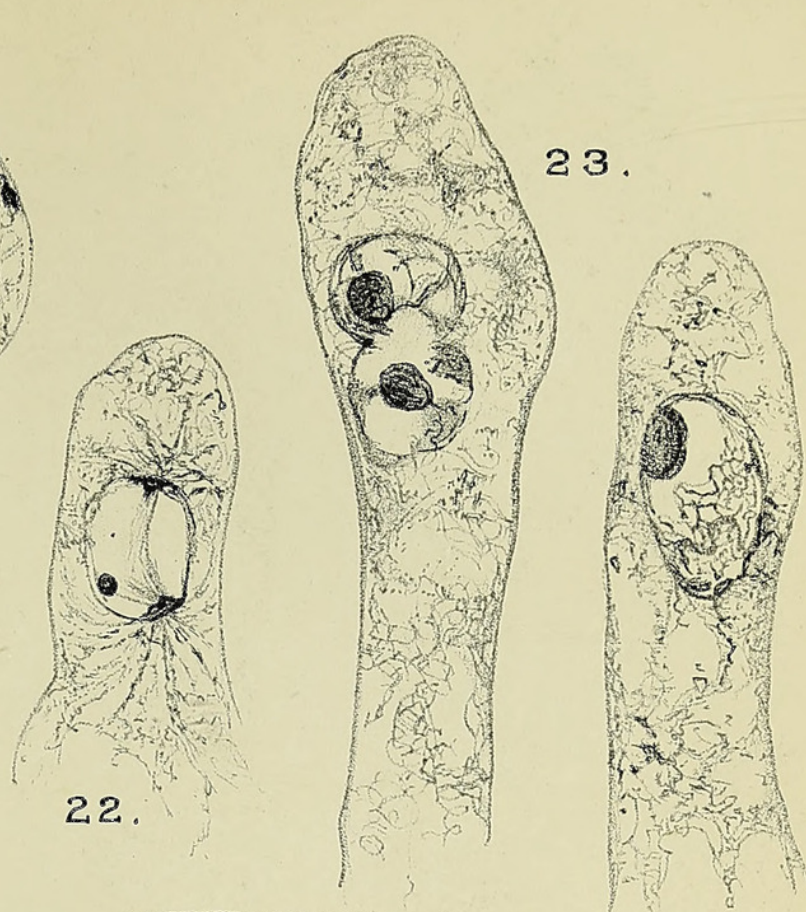

21.
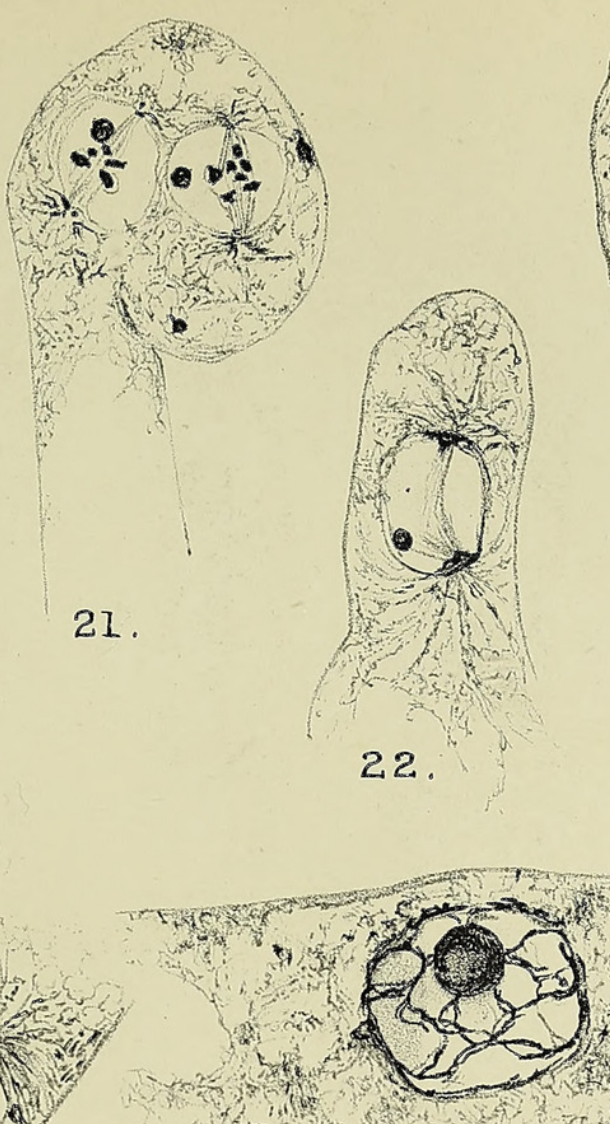

25.
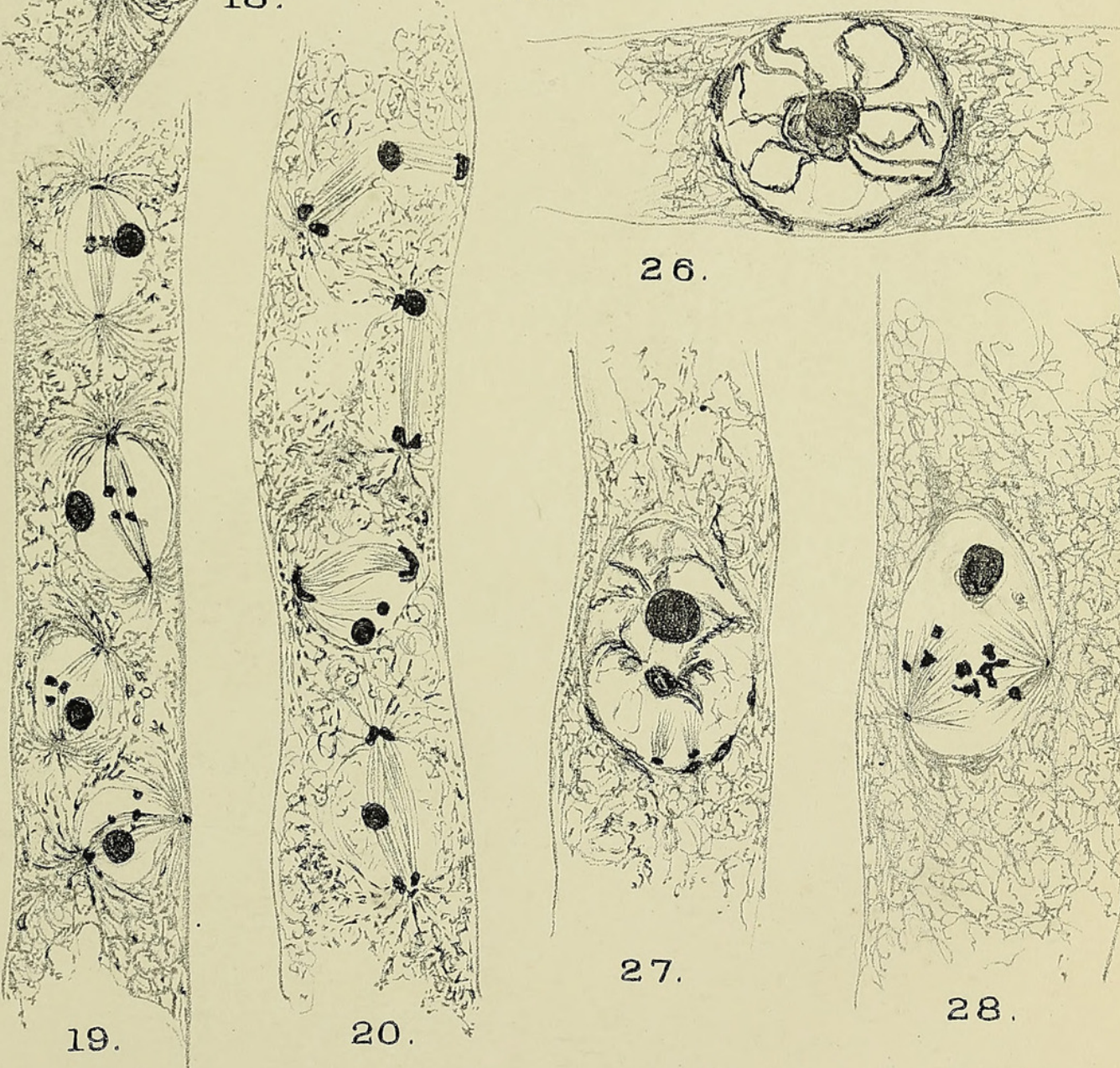

26.
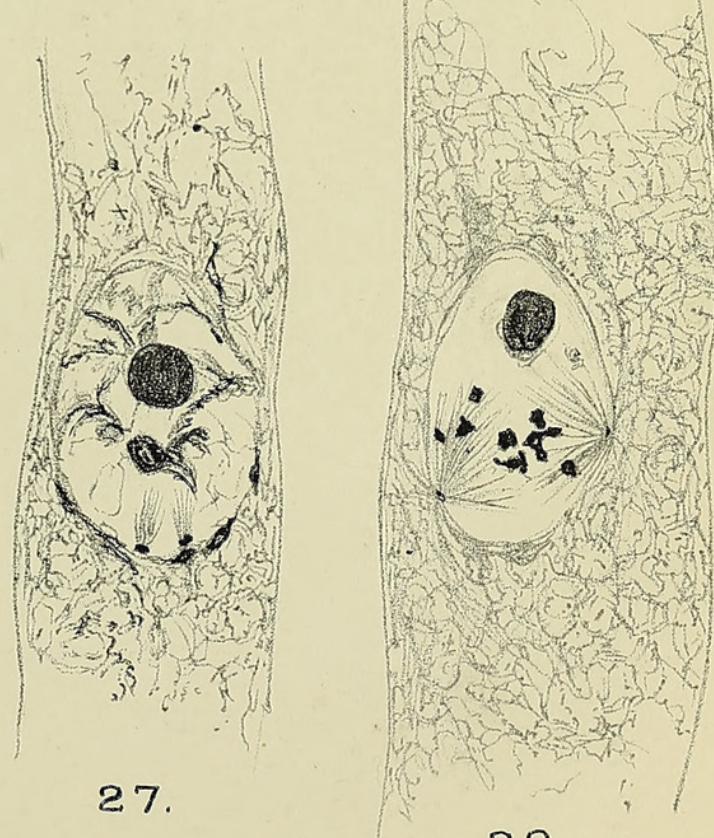

28 
Atrials of Botany.
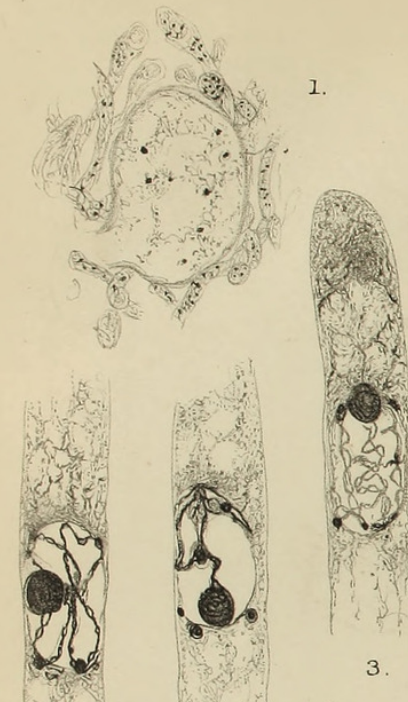

5.

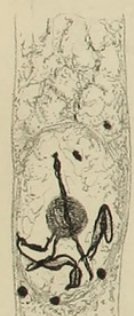

4.

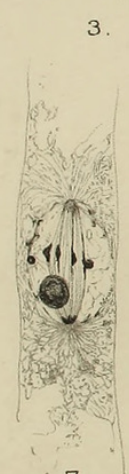

$$
7
$$

6.

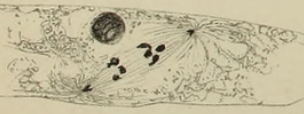

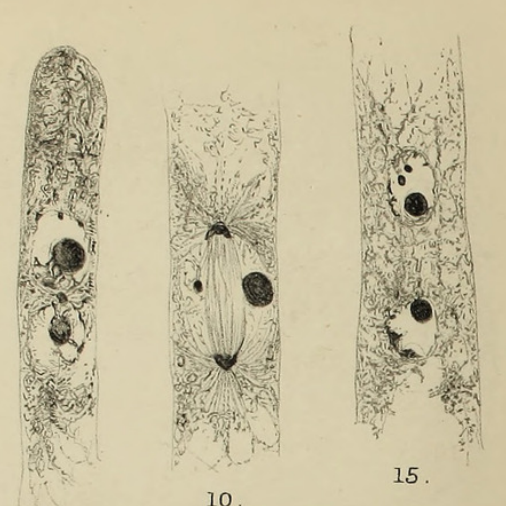

$$
2 \text {. }
$$
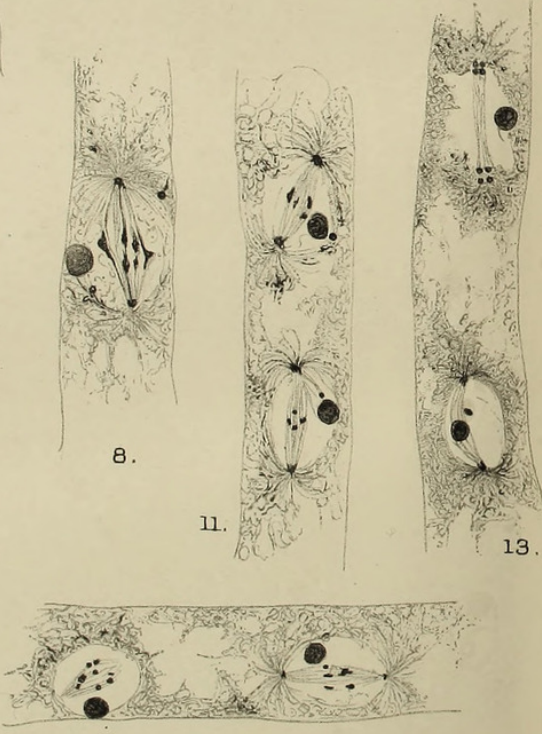

12

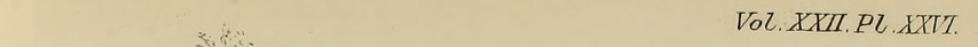

VoZ. XXII. PZ . XXIT.

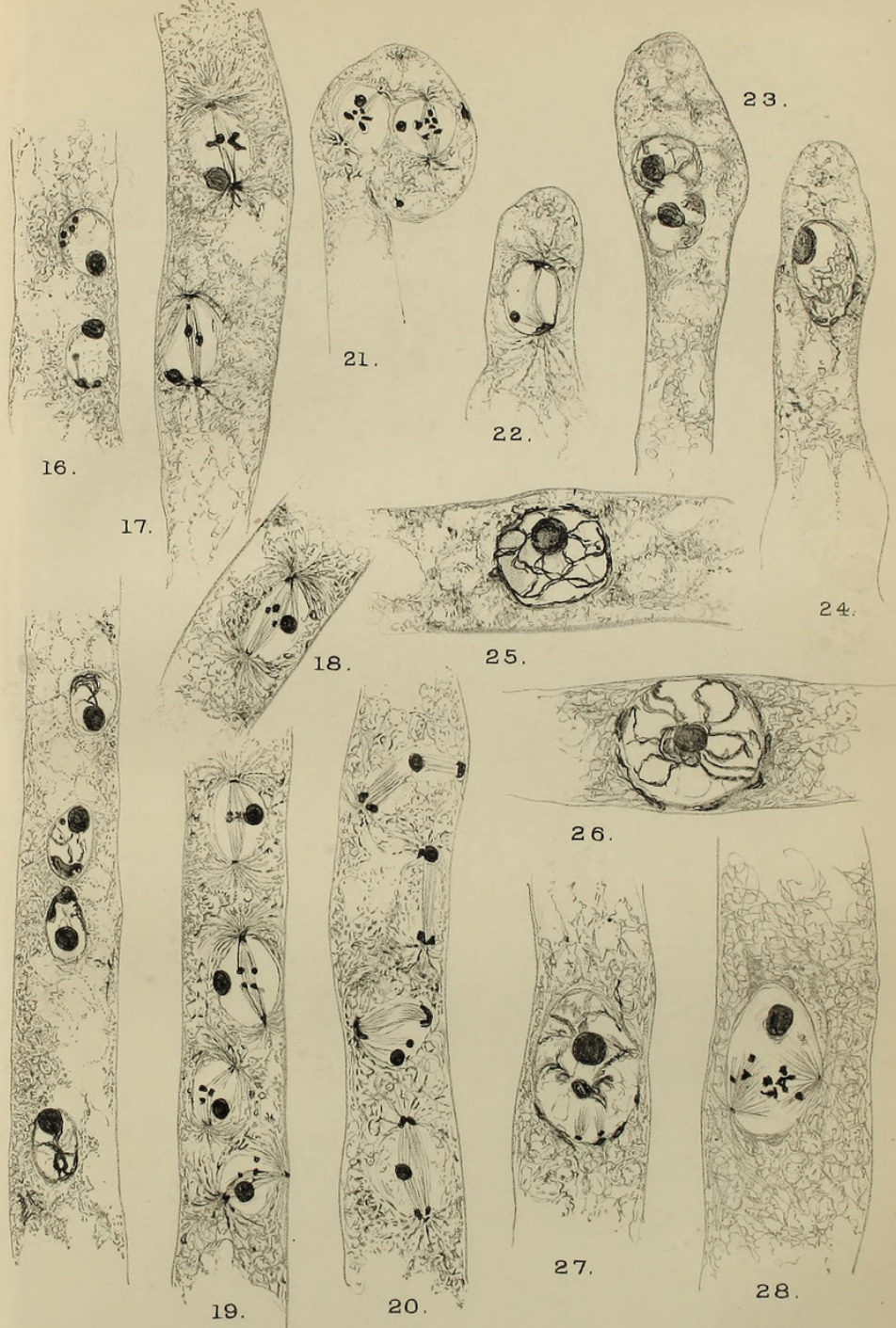

Huth lith et imp. 
Annats of Botany.
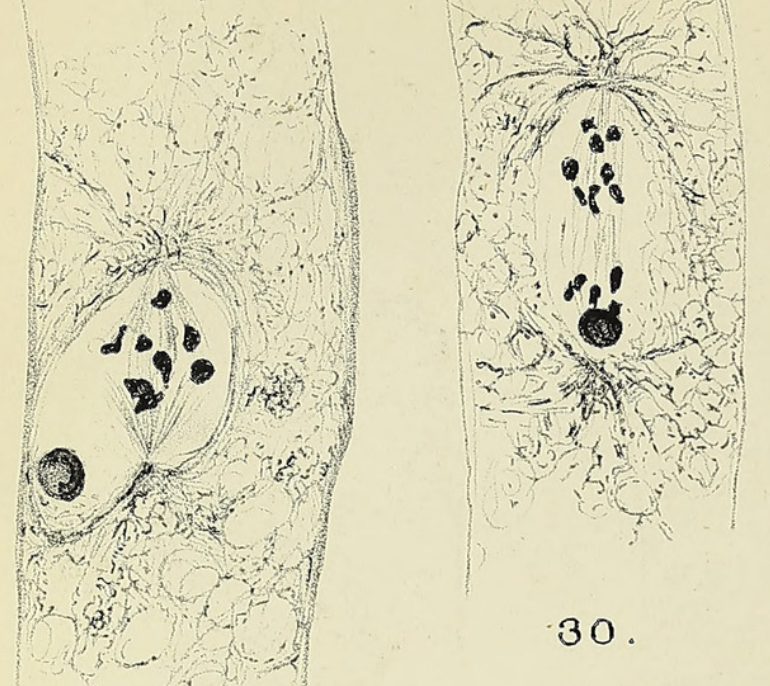

30.

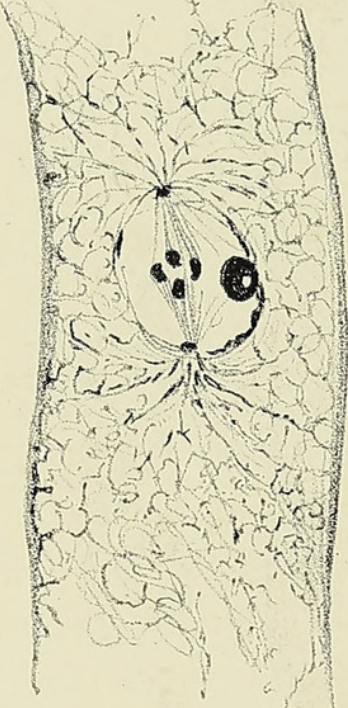

33
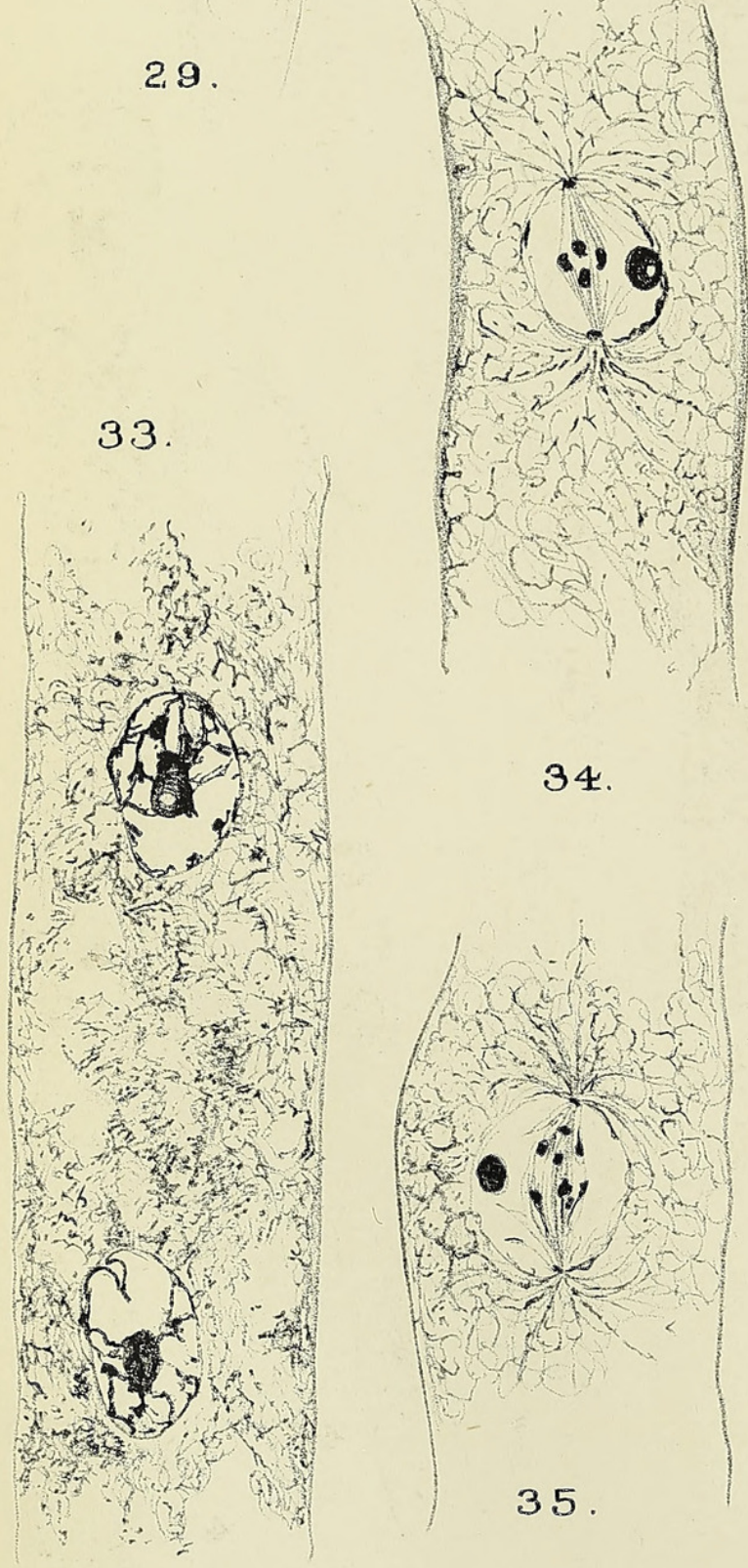

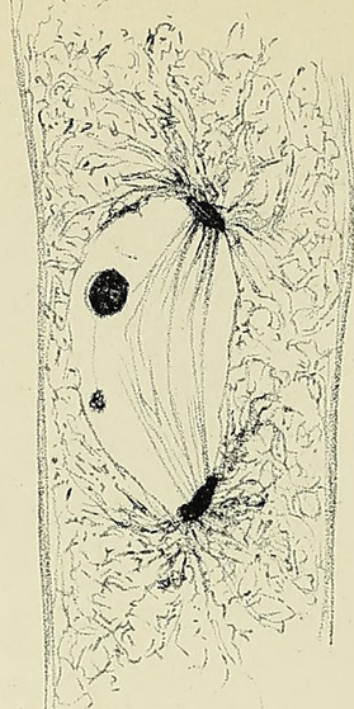

31.

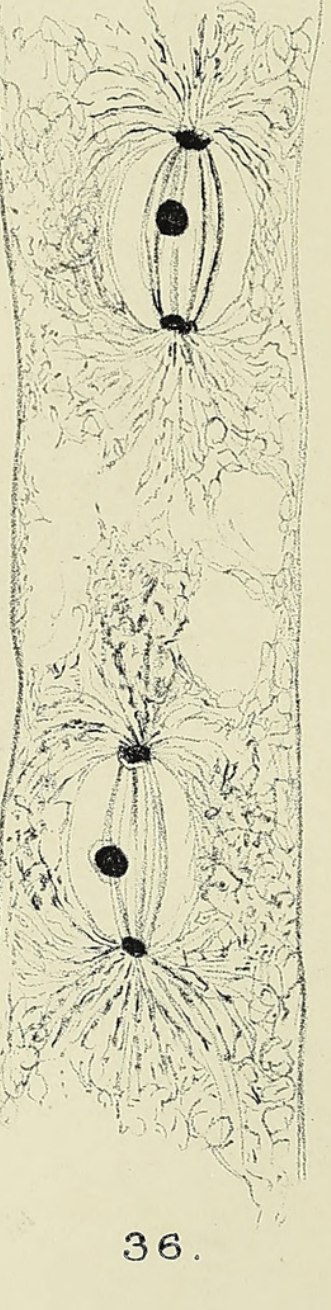

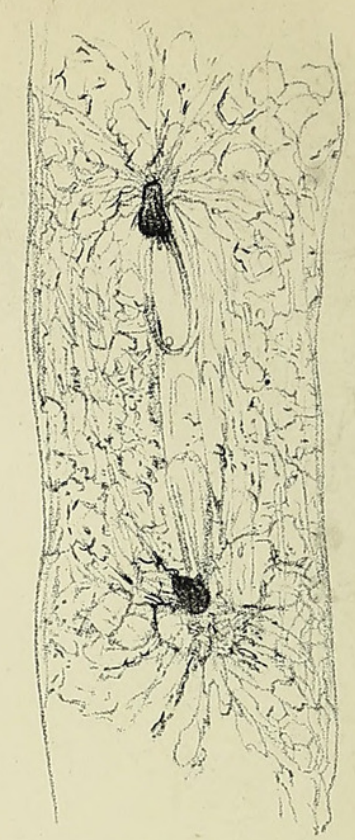

32.

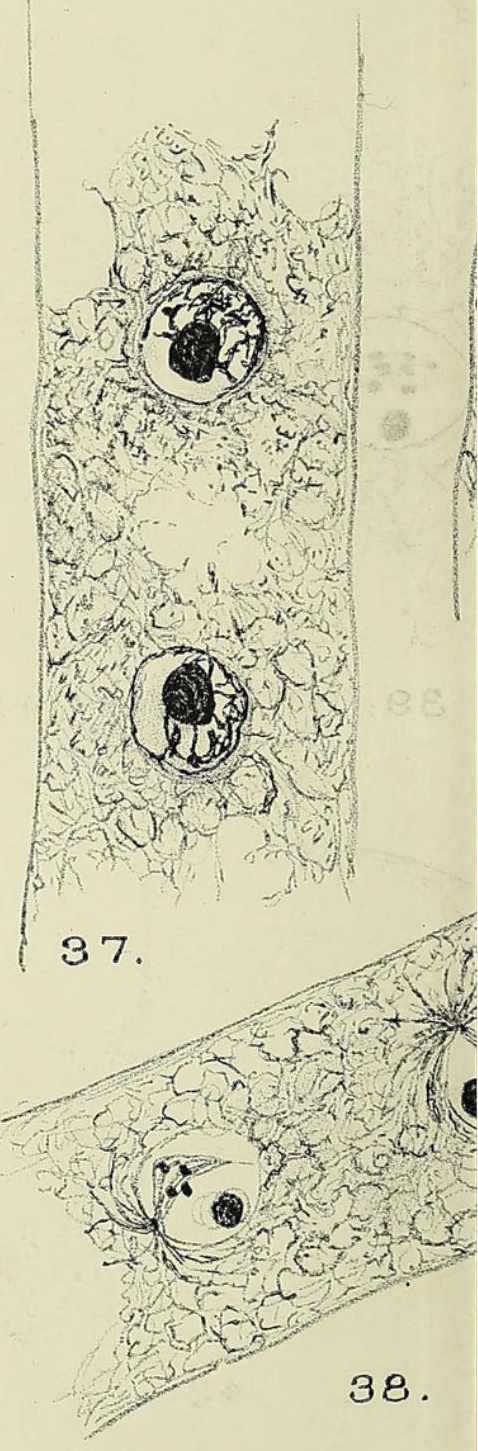

Fraser del. 
VoL.XXII,PL.XXVII.

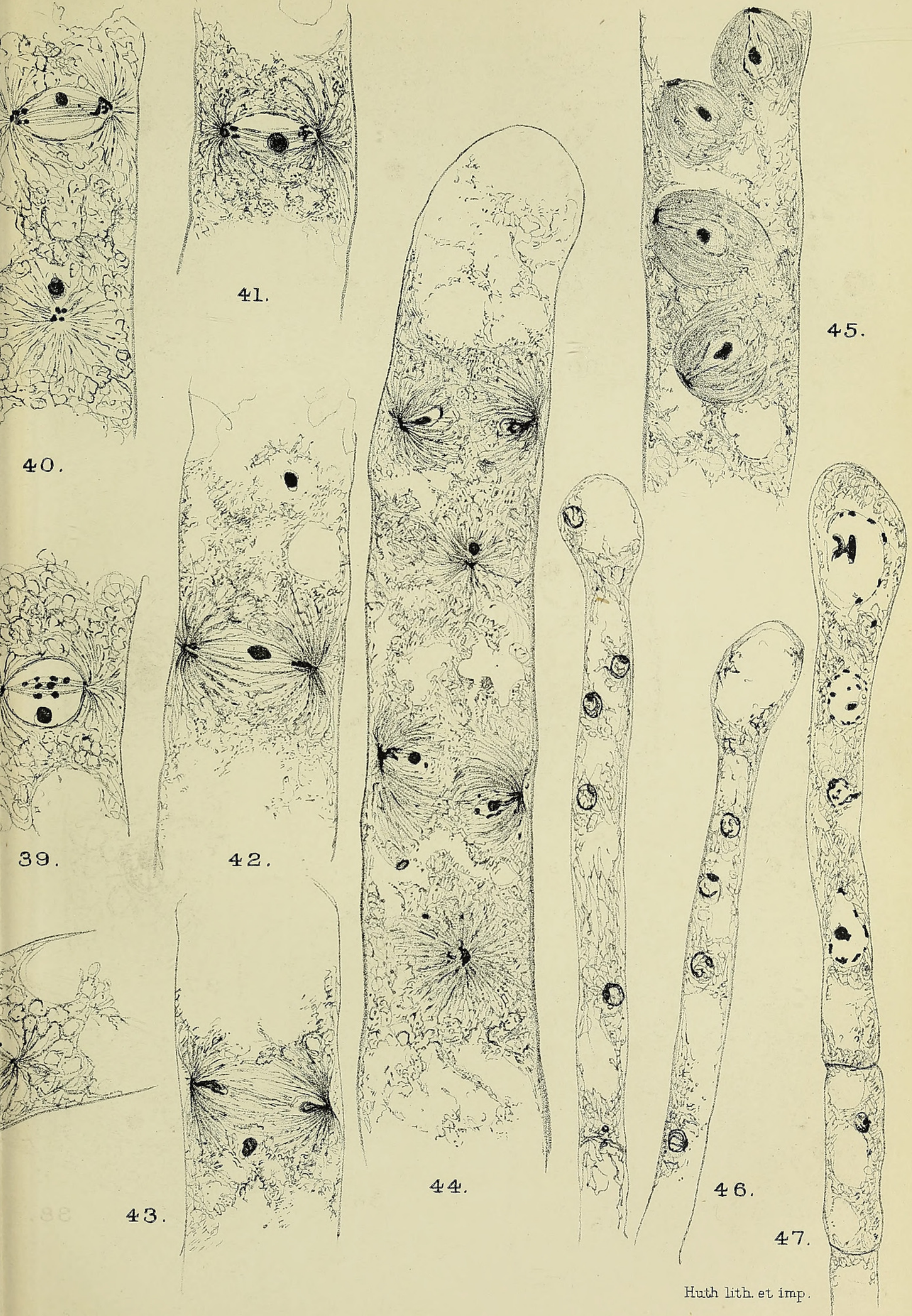




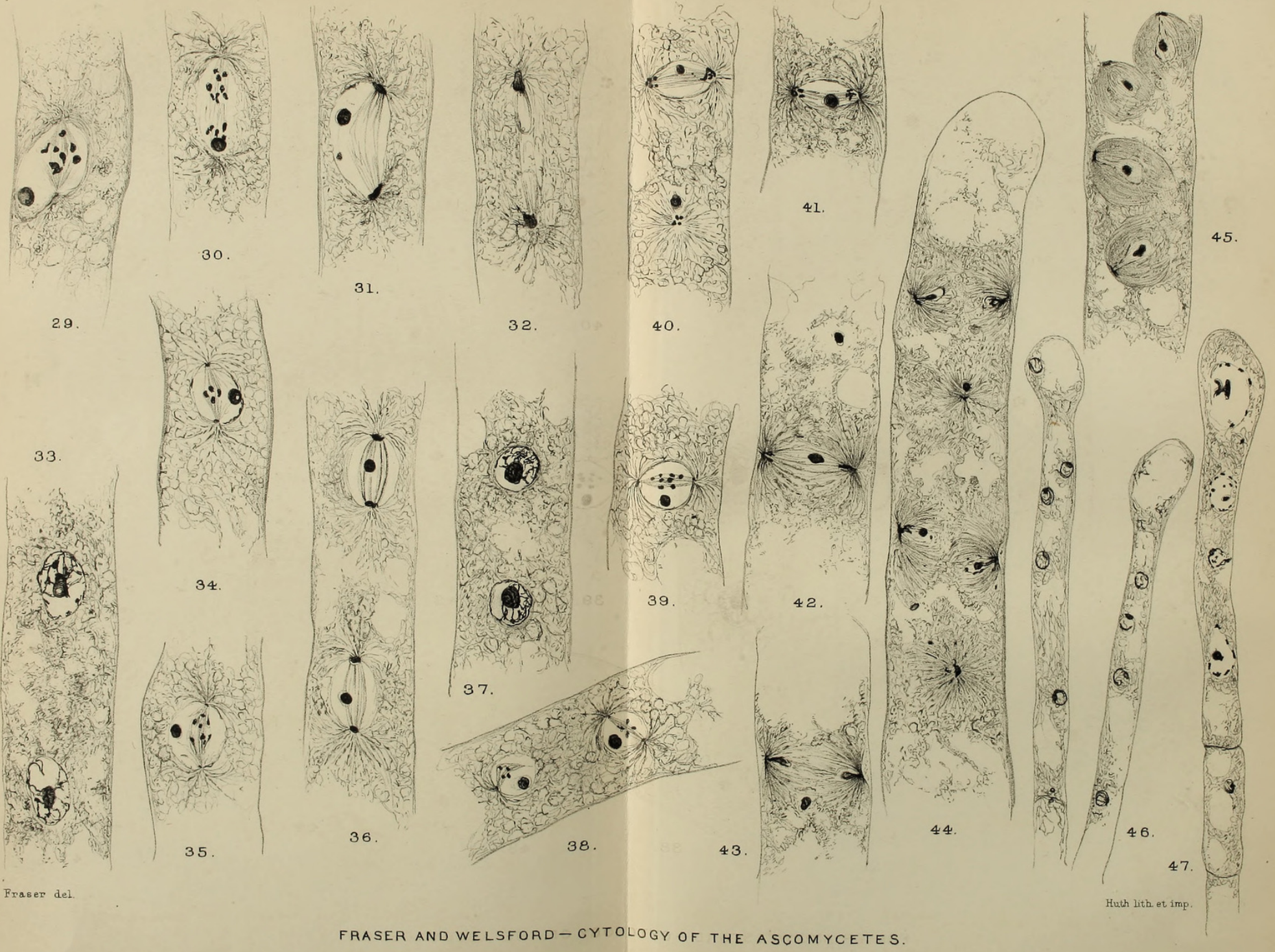




\section{$2 \mathrm{BHL}$ Biodiversity Heritage Library}

Gwynne-Vaughan, H. C. I. and Welsford, E. J. 1908. "Further contributions to the cytology of the Ascomycetes." Annals of botany 22, 465-477. https://doi.org/10.1093/oxfordjournals.aob.a089183.

View This Item Online: https://www.biodiversitylibrary.org/item/232525

DOI: https://doi.org/10.1093/oxfordjournals.aob.a089183

Permalink: https://www.biodiversitylibrary.org/partpdf/318919

\section{Holding Institution}

Smithsonian Libraries

\section{Sponsored by}

Biodiversity Heritage Library

\section{Copyright \& Reuse}

Copyright Status: Not in copyright. The BHL knows of no copyright restrictions on this item.

This document was created from content at the Biodiversity Heritage Library, the world's largest open access digital library for biodiversity literature and archives. Visit BHL at https://www.biodiversitylibrary.org. 